in press: The American Journal of Psychology

Running head: Will

\title{
Nietzsche's Last Will
}

Review of 'The will to nothingness.

An essay on Nietzsche's On the genealogy of morality'

by Bernard Reginster

Joachim I. Krueger

Brown University

2,525 words of text

(sans references)

Correspondence:

Joachim I. Krueger

Department of Cognitive, Linguistic \& Psychological Sciences

Brown University

190 Thayer St.

Providence, RI 02912

Phone: (401) 863-2503

Home page: http://research.brown.edu/research/profile.php?id=10378

Keywords: morality, rationality, Nietzsche, human nature

Note: This book is published by Oxford University Press, New York, NY, 2021. ISBN 978-0-19-886890-3, list price: \$68.60, 224 pages, hardcover. 


\section{Do not pass by the oasis without stopping to drink!}

- Otto Gross (to Carl Jung) denouncing renunciation

Moral outrage is the rock on which social psychology is built. Following Gustave Le Bon, early theorists and observers of the human scene warned of the violent potential of crowds. Following Solomon Asch, early experimentalists provoked crises of conscience in the laboratory and showed that many ordinary people obey, conform, or fall into apathy when, morally speaking, they shouldn't. Research on prejudice, selfishness, and (self-)deception exploded, painting a picture of a species difficult to love (Krueger, 2012). The movement of positive psychology sought to overcome the moralization of bad behavior, but this approach too is drenched in moral assumptions and values. Positive psychology looks for ways in which people may be helped to not only be happy but to be 'good' (Peterson \& Seligman, 2004). Most recently, the fuzzily bounded field of moral psychology has looked to map the moral judgments of ordinary people, judgments which the researchers then, often implicitly, judge on their supposed moral merits (Haidt, 2013). As most of these researchers themselves are ordinary people who have not - unlike Kant - been roused from their dogmatic slumbers, research is liable to confirm moral prejudice (Stanovich, 2021).

Philosophy can help. Philosophers seek to explore the origins of morality and to propose standards that have normative force. To be fair, some psychological research is concerned with the biological and cultural foundations of morality as, for example, when it asks how the emotion of disgust was refined into the sentiment of disdain (Rozin, Haidt, \& McCauley, 2008). Yet, few psychologists ask why we, as a culture, have this morality and not another (see Rai \& Fiske, 2011, for an excellent exception). The prevailing morality rewards niceness and altruism and punishes nastiness and selfishness. This morality is essentially a Christian morality.

Friedrich Nietzsche called for a revaluation of values. He wanted to revive and cultivate Presocratic heroic virtues. Yet, Nietzsche's Übermensch was not to be a reborn Achilles, but a new sort of human being, a being that knows excellence and that has no notion of evil. Some read Nietzsche when they are 18 years old and then forget about him, while others retain the vague notion that his ideas 
inspired assorted totalitarians, existentialists, postmodernists, and other enemies of the Enlightenment. Poor Friedrich!

With "The will to nothingness" (hereafter: Will), Bernard Reginster presents a fresh assessment of Nietzsche's writings on the origins of contemporary morality, focusing on 'The Genealogy of Morals' but drawing from Nietzsche's entire life's work. Bernard is a friend and colleague at Brown University, a fact I hasten to reveal. I have co-taught a course on The Psychology and Philosophy of Happiness with him (Krueger \& Reginster, 2022), an experience that has introduced me to philosophical methods of inquiry and to Bernard's mode of analysis in particular. I shall not review Will on formal philosophical grounds. My goal is rather to bring this work to the attention of psychologists, as much can be learned from it. I see three main lessons: First, a system of moral values, as it exists in a society, has a causal history or genealogy, which can be explored. Second, as noted above, other moral systems have existed at other times, and they do exist in different places today - even in different pockets of the same society. Thus, Nietzsche and Reginster rightly caution against moral inevitabilism. Third, to the extent that Nietzsche's diagnosis of slave morality and its dangers is sound, we must ask if we can detect the workings of Ressentiment in our post-Christian era.

Will summarizes, discusses, and critiques Nietzsche in five chapters. Let us, without aiming for exhaustiveness, review what we learn. The first chapter explores the foundations of morality. The issue of foundations is easily overlooked because a successful morality provides affects and beliefs that we experience as being so natural that we won't wonder about their origins or ask about alternatives. Having much in common with religion, morality often relies on religion to ground itself. Yet, this reliance was questioned long ago by Plato in the Euthyphro. Either God issued arbitrary commands or He derived His commands from a pre-existing logic or 'logos'. If the former, God is a mad-dog (and thus immoral) tyrant; if the latter, we can directly appeal to the logos and God can go and play golf (Pinker, 2021, nicely summarizes this argument of the elimination of God as a morality-giver). To understand morality properly, we need a naturalistic, causal, and psychological account. Nietzsche supplies one. 
The second chapter unpacks the deep and difficult concept of Ressentiment, its depth and profundity being deeper and more profound in French than in English (resentment). The German language does not even have a word for it. Nietzsche sees Christian morality and its secular offshoots (e.g., the moral perspectives proposed by the Enlightenment philosophers Hume, Kant, and Bentham, among others) as reactions against an older aristocratic warrior morality. The warrior morality pitted the strong against the weak. Might makes not only right but good. The weak hated this. They felt ressentiment. Being weak, they realized they could not overthrow the warriors to satisfy their own will to power. They felt ressentiment, which is, Reginster explains, "a response to suffering when it is experienced as raising global doubts about your strength" (p. 74). With ressentiment, the weak cast the strong as evil and themselves as good. This inversion was the original revaluation of values. Once the revaluation was achieved, it licensed revenge in the guise of justice.

The triumph of the weak was partial, and this is what makes their new morality dangerous. First, it is not the whole lot of the weak masses that humbles the strong with clever moralizing; the assault on the strong is the prerogative of priests, a caste which, rather than liberating them, perpetuates the enslavement of the weak with the added convenience (for the priests) that the slaves no longer know that they are slaves, but instead enjoy the dubious and self-destructive benefits of ressentiment. Second, the weak continue to suffer because their revenge on the strong is more imaginary than real. If they escaped the yoke of the strong, they now find themselves ruled by priests who not only tell them what to do but also how to feel and what to think (see Schelsky, 1975, for the resurgence of a non-Christian priestly caste of intellectuals). If the masses share the priests' ressentiments against the warriors, they now have reason to resent the priests - but they cannot admit this sentiment to consciousness because their new morality forbids it. In short, the victory of the priests over the masses is more complete than their victory over their rivals, the warriors.

The third chapter explains how ressentiment provides the psychological foundation for the lust for punishment. "What passes off as a call for justice," Reginster writes," may be, in reality, a thirst for revenge" (p. 57). A critical psychological ingredient is the belief in the freedom of the will (Malle, 
Guglielmo, \& Monroe, 2014). If an action, and a moral transgression in particular, is thought to be freely chosen, it follows that the transgressors could have acted differently, and because they did not do so their deserts are just. Nietzsche put it bluntly in the Twilight of the Idols. "The doctrine of free will has been invented essentially for the purpose of punishment, that is, of finding guilty" (quoted in Will, p. 104). This view is not as crazy as it seems; data support it (Clark, Luguri, Ditto, Knobe, Shariff, \& Baumeister, 2014). It should be noted, however, that while Catholicism, like Judaism, insists on the freedom of the will, some Protestant sects do not (Krueger \& Acevedo, 2008). Perhaps, when a punitive slave morality can coexist with the doctrine of predestination, it has sources other than the belief in the freedom of the will. One such source is the doctrine of essential human equality. Whereas a warrior morality assumes the existence of inequality as a natural and desirable state of affairs, a slave morality abhors it and seeks to punish the strong. Revenge presumes to be justice. In the current climate, when a powerful person typically a man - is brought low (i.e., 'canceled'), he is presumed to be guilty in the moral, if not in the legal, sense. he brought it upon himself, didn't he? Calvinism still does not fit well into this conception of equality, and guilt, because it assumes God has already decided whom to save.

Through punishment, the weak (the good) seek to achieve superiority over the strong (the evil). Yet, slave morality does not work as advertised. Revenge often stalls at the level of the imagination (after all, the strong are stronger than the weak). The indignation of the weak may be 'noble' but it is toothless, like the hoarse "barking of sick dogs" (Genealogy of Morals, cited in Will, p. 106). The carnival of grievances in contemporary culture may, in time, be seen as a post-Christian drama following the same script (as foreseen by Schelsky, 1975, and recently diagnosed by Stanovich, 2021, reviewed in Krueger, in press). When revenge is frustrated, cognitive dissonance reduction offers a psychological band aid. Decades before Festinger (1957), the philosopher Max Scheler (1913/1961) suggested that the stymied avenger, instead of convincing himself that the grapes are sour, concludes that he does not value sweetness. Revenge may be sweet, but who needs it, he asks. This is a bit of self-deception and Reginster concludes chapter by asking how self-deception can be achieved. Reginster favors the mechanism of 
sustained pretense. A counterfactual belief such as 'Our revenge has succeeded' cannot "be produced by an act of will" (p. 118), but it can take root if one pretends to believe it long enough.

The fourth chapter links acts of punishment to the experience of guilt. Guilt arises from the idea of having been able to act otherwise, that is, it arises from the doctrine of free will. Guilt is a debt that must be repaid, and as guilt is an internalized moral emotion, the transgressor must seek and welcome his just deserts. It seems unlikely, though, that guilt came into the world with the advent of slave morality. Warriors too, we suspect, have the capacity to feel guilty lest we assume, as Nietzsche seems to, that they enjoy their cruel outrages against the weak without any tinge of em- or sympathy. Beyond guilt lies the even darker emotion of shame (Tangney, Stuewig, Mashek, 2007). Shame comes into full flush when the specter of one's own impotence stares one in the face. The will to power is thwarted and there is no behavioral remedy besides withdrawal. The contrast with shame highlights the functional value of guilt, but we wonder which constructive role shame might play in the mind's moral architecture.

The discussion of guilt as indebtedness expands into an exploration of general issues of transactional behavior. Reginster reflects on promise-making and trust and their implications for social status. Folk psychology assigns the trustor moral credit (Krueger, Massey, \& DiDonato, 2008) and does so presumably because it considers the trustor weak. It is rather the trustee for whom being trusted "is a mark of distinction" (Nietzsche in the Genealogy, cited in Will, p. 125). The trustor is further weakened by the transaction. "When you trust me, you surrender some of your power and control," Reginster (p. 137) observes. The trustor's will to power should favor mistrust, but a slave morality demands trust as the right thing to do (Evans, Ong, \& Krueger, 2021). To not trust generates guilt before God, the priests, and anyone bold enough to make promises or to demand being trusted.

Again, the psychological mechanisms set into gear by slave morality succeed only partially. Slave morality demands too much. If sin is original, baked in, and inexpiable, guilt degenerates into shame, and the desert is an infinite disutility (i.e., brim \& firestone). The enslaved human being senses, and accepts, his condemnation and bears its toxicity. Nietzsche, it seems, felt sympathy for the poor sod. "Here is a sickness [. . .] the most terrible sickness that has ever raged in man" (Genealogy; cited in Will, p. 152). 
The fifth and final chapter introduces the ethic of ascetism as the will to power's last stand. When everything fails, the enslaved moralist can only mortify himself and seek moral credit and status by doing so more cruelly than the fellow next door. The 'when-everything-fails' hypothesis helps explain why asceticism has not died out, but it does not overcome its paradox. Reginster notes that asceticism depletes the very energy it promises to replenish. This is yet another example of slave morality's limited success and toxic failure. Moral man is reduced to a Kafkaesque figure who starves himself to death in order to make a living (Kafka, 1924). He "would rather will nothingness than not will" at all (Genealogy, cited in Will, p. 167). Doing so, he extracts a sense of meaning from his suffering, a sense that can only be illusory - assuming, that is, that there are other senses of meaning that are not illusory.

A survey of the literature on self-regulation in psychology and economics reveals a prevailing "ethic of denial" (Krueger, 2010). Greater inhibitory self-control is seen as both moral and rational. Poor impulse control is the enemy. People eat too much, lust too much, and spend too much. To be moral (and rational), they shall renounce and resist temptation. Slave morality issues proscriptions rather than prescriptions, and many scientists have worked hard to make it look like it has to be so. Many of those who championed a respect for desire - like Otto Gross or Wilhelm Reich - were denounced as decadent or mad. (Heuer, 2017) Where are today's champions of spontaneity, humor, enjoyment, and selfindulgence? Putting a finer point on this, we should ask where is the prudential morality that manages our errors (Swets, Dawes, \& Monahan, 2000)? If impulsive behavior goes wrong, there is a salient Type I error. Conversely, if a pleasure is missed, there is a Type II error. Categorical morality focuses on the eradication of false positives. What's lost is hard to see because false negatives stay, by definition, under the radar. They don't generate pangs of guilt but bring a diffuse kind of melancholia and a sense of a life not well lived. Slave morality is dangerous to your health. Nietzsche asks us to find our inner warrior and to live dangerously. I suspect that Bernard might agree, but he is too much a gentleman to say it out loud.

In closing, we may ask if the contrast between slave and warrior morality is myopic. Is it fair, or even accurate, to lump the Enlightenment moralities of Hume, Kant, or Bentham with the churchly morality they sought to overcome? Hume, betting on sympathy, Kant betting on duty, and Bentham 
betting on efficiency proposed moral systems that do not require ressentiment or asceticism (well, Kant, perhaps, the latter). They do not assume a will to power, and they do not denigrate the will to relate (Gross, 1919); and that's not nothing.

\section{References}

Clark, C. J., Luguri, J. B., Ditto, P. H., Knobe, J., Shariff, A. F., \& Baumeister, R. F. (2014). Free to punish: A motivated account of free will belief. Journal of Personality and Social Psychology, 106, 501-513.

Evans, A. M., Ong, H. H., \& Krueger, J. I. (2021). Social proximity and respect for norms in trust dilemmas. Journal of Behavioral Decision Making, 35, 657-668.

Festinger, L. (1957). A theory of cognitive dissonance. Evanstone, IL: Row, Peterson.

Gross, O. (1919). Zur funktionellen Geistesbildung des Revolutionärs. Räte-Zeitung, 1(52), 64-70.

Haidt, J. (2013). Moral psychology for the twenty-first century. Journal of Moral Education, 42, 281297.

Heuer, G. M. (2017). Freud's 'outstanding' colleague / Jung's 'twin brother.' The suppressed psychoanalytic and political significance of Otto Gross. New York, NY: Routledge.

Kafka, F. (1924). Ein Hungerkünstler. Berlin, Germany: Die Schmiede.

Krueger, J. I. (2010). Discounting and the ethic of denial. Psychology Today Online. https://www.psychologytoday.com/us/blog/one-among-many/201007/discounting-and-the-ethic-denial

Krueger, J. I. (2012). The (ir)rationality project in social psychology: A review and assessment. In J. I. Krueger (Ed.). Social judgment and decision-making (pp. 59-75). New York, NY: Psychology Press.

Krueger, J. I. (in press). Twilight of rationality. Review of 'The bias that divides us: The science and politics of myside thinking' by Keith E. Stanovich. American Journal of Psychology.

Krueger, J. I., \& Acevedo, M. (2008). A game-theoretic view of voting. Journal of Social Issues, 64, 467-485.

Krueger, J. I., Massey, A. L., \& DiDonato, T. E. (2008). A matter of trust: From social preferences to the strategic adherence to social norms. Negotiation \& Conflict Management Research, 1, 31-52.

Krueger, J. I., \& Reginster, B. (2022, January 7). What is happiness? A philosopher and a psychologist discuss meaning, politics, and the pleasures of disagreement. Chronicle of Higher Education. https://www.chronicle.com/article/what-is-happiness

Malle, B. F., Guglielmo, S., Monroe, A. E. (2014). A theory of blame. Psychological Inquiry, 25, 147-186. 
Peterson, C. \& Seligman, M. E. P. (2004). Character strengths and virtues: A handbook and classification (pp. 461-475). New York, NY: Oxford University Press.

Pinker, S. (2021). Rationality. What it is. Why it seems scarce. Why it matters. New York, NY: Viking.

Rai, T. S., \& Fiske, A. P. (2011). Moral psychology is relationship regulation: Moral motives for unity, hierarchy, equality, and proportionality. Psychological Review, 118(1), 57-75

Rozin, P., Haidt, J., \& McCauley, C. R. (2008). Disgust. In M. Lewis, J. M. Haviland-Jones, \& L. F. Barrett (Eds.), Handbook of emotions (pp. 757-776). The Guilford Press.

Scheler, M. (1913/161). Ressentiment. New York, NY: Schocken. Original published in German.

Schelsky, H. (1975). Die Arbeit tun die anderen. Klassenkampf und Priesterherrschaft der Intellektuellen. Opladen, Germany: Westdeutscher Verlag.

Stanovich, K. E. (2021). The bias that divides us: The science and politics of myside thinking. Cambridge, MA: MIT Press.

Swets, J. A., Dawes, R. M., \& Monahan, J. (2000). Psychological science can improve diagnostic decisions. Psychological Science in the Public Interest, 1, 1-26.

Tangney, J. P., Stuewig, J., Mashek, D. J. (2007). Moral emotions and moral behavior. Annual Review of Psychology, 58, 345-372. 